\title{
Factors Influencing Market Price of Fish in Obio-Akpor Local Government of Rivers State, Nigeria
}

\author{
Ike-Obasi, J.C \\ African Regional Aquaculture Center/Nigerian Institute for Oceanography and Marine Research, Aluu. \\ P.M.B. 5122, Port Harcourt, Rivers State, Nigeria
}

\begin{abstract}
*Corresponding Author: Ike-Obasi, J.C, African Regional Aquaculture Center/Nigerian Institute for Oceanography and Marine Research, Aluu. P.M.B. 5122, Port Harcourt, Rivers State, Nigeria
\end{abstract}

\begin{abstract}
This study evaluated some factors influencing the market price of fish in some markets located in Obio-Akpor Local Government of Rivers State, Nigeria. The respondents of the study were: fish vendors and consumers. A total of 70 questionnaires were distributed in the study. Data from the study were collated and descriptive statistics were used to quantify and analyzed the gathered data. Based on the findings of the study, among the eight identified factors affecting the market price of fish, fish size (35.71\%) and quality (30.00\%) were found to greatly affect the market price of fish. However, factors such as consumer's choice (4.29\%), and seasonal effect (4.29\%) were considered as the lowest factor affecting the market price of fish in the study area. Furthermore, it was found that lack of good storage facilities for proper storage of fresh and processed fish $(42.85 \%)$ and government policy $(31.43 \%)$ were major challenges affecting the stability of fish price in the study area.
\end{abstract}

Keywords: Fish size, Price, Market, Fish quality, Demand and Supply

\section{INTRODUCTION}

Fish and its products are essential constituents in the feeding regime of most Nigerians, to some extent, because it is comparatively a cheaper protein source when compare to other sources of animal protein [1]. Additionally, fish constitutes about $40-50 \%$ of the animal protein intake of the average Nigerian [2,3]. It plays an important role in improving the food security and nutritional status of many families in the country. Many families depend largely on fish, on a daily basis. The fish is consumed indifferent forms as smoked, dried, fried or steamed [4.5]. Also fish have been described as the sole accessible and affordable source of animal protein for poor household in urban and rural areas [6]. The importance of fish as crucial-elements in the diets of family member such as infants, young children and pregnant women, is now widely recognized [7]. Most of the fishes consumed by the families in different parts of the country come mostly from three main sources, capture fisheries, aquaculture and imported fish (Frozen and Stock fish). Their prices vary from one locality to another, which largely depends on demand and level of urbanization $[8,9]$.

Marketing can be described as a process of exchanging goods and services from one person to another with reference to price [10]. While, fish market is a place used for marketing of fish and fish products from time to time [11]. However, fish marketing basically consists of all the activities involved in delivering fish from producer to the final consumer through a distribution channel [12]. Conversely, the market mechanisms have to be proficient to be able to play the critical role of propelling profit of a fish product. Equally, an efficient market system therefore is the one that offer acceptable and cost effective services to consumers or one that maximize the ratio of input and output of marketing [13]. In Nigeria, fish marketing system varies from one area to another depending on type of fish product, market location, and the distance between source of supply of fish product and retailer and ultimately to consumer [14]. Fish supply and marketing can be influenced by shortage of supply, price fluctuation due to drying up of the source and spoilage during transportation from location to another [15]. 
In different parts of the country, the prevailing prices of fish have been reported to vary considerably from one market location to another, either in rural or urban centers [16], For instance, in the inland markets, the prices of fish are affected by the seasonal competition from other sources of animal protein [17]. Conversely, Aguero [18], claimed that there are a number of varying factors affecting the market price of fish. Few of these dealt on freshness and quality measurement, domestic price differentials, storable and non-storable products and production-retail price differentials. It is important, therefore, to close examine the formulation of the market price of fish based on the varying factors. In view of this situation, this study assessed the factors affecting the market price of fish in Obio-Akpor Local Government of Rivers State.

\section{Materials ANd Methods}

The study was conducted in Obio/Akpor Local Government Area (LGA), Rivers State, Nigeria. Obio/AkporLGA is one of the two LGAs in Port Harcourt metropolis, Rivers State, Nigeria. ObioAkpor is bounded by Port Harcourt (Local Government Area) to the south, Oyigbo to the east, Ikwerre to the north, and Emohua to the west. It is located between latitudes $4^{\circ} 45^{\prime} \mathrm{N}$ and $4^{\circ} 60^{\prime} \mathrm{N}$ and longitudes $6^{\circ} 50^{\prime} \mathrm{E}$ and $8^{\circ} 00^{\prime} \mathrm{E}$. Port Harcourt is the administrative capital of Rivers State, in the Niger Delta area of Nigeria. Port Harcourt lies between $4.75^{\circ} \mathrm{N}$ and $7^{\circ} \mathrm{E}$ with network of rivers and tributaries (e.g., New Calabar, Orashi, Bonny, Sombrero and Bartholomew Rivers) which provide great opportunity for fish farming [19]. Obio/Akpor L.G.A is one of the Agricultural Zones of Agricultural Development Programs of Rivers State. Simple random sampling method was used for the study. The study made use of the descriptive - survey method using researcher-made questionnaire as main instrument to gather data. The researcher-made questionnaire was composed of questions categorized into two (2), one for each of the intended respondents: fish vendors and consumers. Informal interviews and observation were made to verify data and ascertain the validity of the respondents' answers. The collected data was analyzed using descriptive statistics (such as percentages and frequency tables.

\section{RESUltS}

The socio-economic characteristics of the respondents in the study area are presented in Table 1. Most of the respondents $(44.26 \%)$ were within the age group of $36-50$, which was followed by $26-35$ (24.28\%) and $15-25(18.57 \%)$ while the lowest (12.87\%) was recorded in the age group of 50 and above. Also, in respect of respondent's sex, $82.86 \%$ of them were females, while $17.14 \%$ were males. The household size which refers to the number of people living under one roof at a time, ranges between $1-10$, with the highest $(50.00 \%)$ of $6-10$ persons in the present study. The factors affecting the market price of fish are presented in Table 2. From the respondents, the size and quality of fish account for the highest value of $35.71 \%$ and $28.57 \%$ respectively. While, consumer choice and seasonal effect recorded the lowest value of $4.29 \%$. The challenges to stability of fish price in the study area are presented in Table 3.Lack of good storage facilities (42.85\%) and government policy (31.43\%) account for the highest percentage, while activities of government agents recorded the lowest value of $7.14 \%$.

Table1. Socio-economic Variable of the Respondents $(n=70)$

\begin{tabular}{|c|c|c|}
\hline Parameters & Frequency & Percentage \\
\hline \multicolumn{3}{|l|}{ Age (Years) } \\
\hline $15-25$ & 13 & 18.57 \\
\hline $26-35$ & 17 & 24.28 \\
\hline $36-50$ & 31 & 44.28 \\
\hline 50 and above & 9 & 12.87 \\
\hline Total & 70 & 100 \\
\hline \multicolumn{3}{|l|}{ Sex } \\
\hline Male & 12 & 17.14 \\
\hline $\begin{array}{l}\text { Female } \\
\text { Total }\end{array}$ & $\begin{array}{l}58 \\
70\end{array}$ & $\begin{array}{c}82.86 \\
\mathbf{1 0 0} \\
\end{array}$ \\
\hline \multicolumn{3}{|l|}{ Marital Status } \\
\hline Married & 58 & 80.00 \\
\hline Single & 10 & 15.83 \\
\hline Divorced & 2 & 4.17 \\
\hline Total & 70 & 100 \\
\hline
\end{tabular}




\begin{tabular}{|c|c|c|}
\hline $\begin{array}{ll}\text { Household Size } & \\
1-5 & \\
6-10 \\
>10 \quad \text { Total }\end{array}$ & $\begin{array}{c}30 \\
35 \\
5 \\
\mathbf{7 0}\end{array}$ & $\begin{array}{c}42.86 \\
50.00 \\
7.14 \\
\mathbf{1 0 0}\end{array}$ \\
\hline \multicolumn{3}{|l|}{ Educational Qualification } \\
\hline Primary & 20 & 28.57 \\
\hline Secondary & 41 & 58.57 \\
\hline Tertiary & $\begin{array}{c}9 \\
70\end{array}$ & $\begin{array}{c}12.86 \\
\mathbf{1 0 0}\end{array}$ \\
\hline \multicolumn{3}{|l|}{ Experience (Years) } \\
\hline $1-5$ & 20 & 28.57 \\
\hline $6-10$ & 33 & 47.14 \\
\hline $11-15$ & 11 & 15.71 \\
\hline 15 and above & 6 & 8.58 \\
\hline Total & 70 & 100 \\
\hline
\end{tabular}

Source: Field Survey (2019)

Table2. Factors Affecting the Market Price of Fish $(n=70)$

\begin{tabular}{|l|l|l|}
\hline Challenges & Frequency & Percentage (\%) \\
\hline Consumers choice & 3 & 4.29 \\
\hline Fish species & 4 & 5.72 \\
\hline Fish Size & 25 & 35.71 \\
\hline Fish Quality & 20 & 28.57 \\
\hline Preservation Methods & 5 & 7.14 \\
Market Location & 5 & 7.14 \\
Fish Availability & 5 & 7.14 \\
Seasonal effect & 3 & 4.29 \\
\hline Total & $\mathbf{7 0}$ & $\mathbf{1 0 0}$ \\
\hline
\end{tabular}

Source: Field Survey (2019)

Table3. Challenges to Fish Price Stability $(n=70)$

\begin{tabular}{|l|l|l|}
\hline Challenges & Frequency & Percentage (\%) \\
\hline Consumers preference & 6 & 8.58 \\
\hline Lack of good storage facilities & 30 & 42.85 \\
\hline Activities of Government Agents & 5 & 7.14 \\
\hline Market Union Activities & 7 & 10.00 \\
\hline Government Policy & 22 & 31.43 \\
\hline Total & $\mathbf{7 0}$ & $\mathbf{1 0 0}$ \\
\hline
\end{tabular}

Source: Field Survey (2019)

\section{DisCussion}

The socio economic characteristics of the respondents indicated that marketing activities are predominant among relatively younger people than the older ones as observed in this study. This is in line with the observation of George and Akinrotimi [20] who reported the similar results among fish marketers in the same local government. The reason may be due to the fact that marketing activities is very demanding and need active individual for its range of activities. Also, the study revealed that females are more than their male counterparts in fish marketing business. This result fall in with the findings of Cliffe et al. [21] who reported the same trend in some communities of Rivers State, Nigeria. They reported that women are more in number than men in marketing of fishery products. It is an area of business that is predominantly dominated by women. The house hold size recorded in this study area is comparatively large. This is consistent with the works of Cliffe and Akinrotimi [22], who reported that families with large number of persons usually engaged in fish marketing as observed in some coastal communities of Niger Delta. The large family as observed in this study indicated that the respondents had and cheap access to un-remunerated family labour. This therefore explains why the use of hired labour in small scale agribusiness enterprise is very low. The respondents were literates and have a lot of marketing experience; this assertion is in line with the 
observation of Amao et al. [23] who observed similar results among fish marketers in Lagos State, Nigeria. The literacy levels as observed in this study will enhance their adoption of new improved marketing strategies. This implies that marketers in the study area have sufficient experience in fish marketing. Experience in marketing is a key factor in marketing efficiency and the longer the years of marketing experience, the more exposed the marketer becomes and the more efficient and effective the marketer is expected to be.

The factor, size of fish, and processing was found to greatly affect the price of fish. Most of the consumers preferred to purchase big size and high quality fish to ensure their health safety and satisfaction. The results obtained is in line with the observation of Ali et al [24] in some markets in Maiduguri, Borno State, Nigeria. The result is further supported by the study of Gordon and Hussain [25]. They opined that the quantity of fish bought to market is determined by many factors, but the size and quality were important determinant of fish prices. In the study area inadequate storage facilities and government policy were the most serious constraint faced by the fish marketers in the area. This result is in line with the findings of Gaya et al. [26] among fish sellers in Yola, Adamawa State, Nigeria. The perishable nature of the fish is a severe barrier to fish marketers this could be attributed to epileptic and irregular power supply in the area which is highly needed for preserving fresh fish which is in high demand in the area. Fresh fish could only be stored for few hours in which case must be sold even when the price is not favourable. The study also revealed that price instability and price fluctuation could also be attributed to some government policies that are not favourable. This finding is in line with CBN [27] that says Prices for fresh fish product responded to the law of demand and supply as no price regulation mechanism exists for fish products in the country.

\section{CONCLUSION}

Fish marketing is an enterprise that is predominant among the youth and women in the study area. And their ages were within the economic active range which favours adoption of marketing development. Most of the fish marketers are married and highly experienced in fish marketing because of families' inheritance. Analysis revealed that fish size and quality were found to be the significant factors influencing price of fish.

\section{REFERENCES}

[1] Akinrotimi, O.A., Onunkwo, D.N., Cliffe, P.T., Anyanwu, P.E. \& Orokotan, O.O. (2007). The role of fish in the nutrition and livelihoods of families in Niger delta, Nigeria. International Journal of Tropical Agriculture and Food Systems, 1(4), $344-351$.

[2] Bayagbona, E. O. (1996). Public and private sector challenges in Nigerian Fisheries. Paper delivered at the 20th Anniversary of Fisheries society of Nigeria (FISON) on 29th October, 1996. Abuja.

[3] Adeniji, H. A. (1987). Fish consumption in Nigeria: implication for fishery development policies. J. West of Africa Fish, 3(2): 151-161.

[4] Akinrotimi, O.A., and Edun, O.M. (2011). Consumer disposition towards Oyster consumption in selected fishing communities of Rivers State, Nigeria. Continental Journal Of Agricultural Economics, 5(1):41-46.

[5] Ugwumba, A. A. A. and Ugwumba, A. A. O. (2003). Aquaculture options and the future of fish supply in Nigeria. The Zoologist, 2(1): 95-98.

[6] Bene, C. and Heck, S. (2005). Fish and food security in Africa. NAGA, World Fish Center Quarterly, 28(3-4): 9-11.

[7] UNICEF (2004). The state of the world's children 2004. Online at http://www.Unicef.org/ sowc04. Accessed on 20th Dec, 2020.

[8] Federal office of statistics (2004). The Nigerian statistical fact sheets on economic and social development Abuja, Nigeria. Pp: 70-81.

[9] Akinrotimi, O. A., Owhonda K. N. and Ibemere I. F. (2005). Brackish water fish farming: A viable option for poverty alleviation in the coastal areas of Niger Delta. Paper presented at fisheries society of Nigeria Conference.17th-25th November, Port Harcourt, Nigeria.

[10] Abila, R. (2015). Fish trade and food security: Are they reconcilable in Lake Victoria. Retrieved from http:// www. fao.org. Accessed on 3rd Of May, 2021.

[11] Abila, R., Mbati, O., \& Othiambo, O. (1997). Analysis of competition in the whole and retail market. Africa Journal of Tropical, Hydrobiology and Fisheries, 7(1): 29-36.

[12] FAO. (2005). Increasing the contribution of small-scale fisheries to poverty alleviation and food security (Technical Guideline for Responsible Fisheries). Rome: FAO. 
[13] Edun, O.M., Akinrotimi, O.A., Uka, A., an d Owhonda, K.N. (2010). Patterns of Mudskipper consumption in selected fishing communities of Rivers State. Journal of Agriculture and Social Research, 10(2): $100-107$.

[14] George A.D.I and Akinrotimi O.A (2021). Socio Economic Characteristics and Bio-Security Measures among Fish Farmers in Some Coastal Communities of Rivers State, Nigeria. International Journal of Research and Scientific Innovation (IJRSI) VIII (I), 190-193.

[15] George, A.D.I., Akinrotimi O.A., \& Nwokoma, U. K. (2021). Socio-Economic Analysis of Artisanal Fisheries in Three Local Government Areas of River State, Nigeria. Journal of Research in Animal Science and Agriculture, 8(2), 16-23.

[16] George, A.D.I., Akinrotimi O.A., \& Nwokoma, U. K. (2021). Productivity and Constraints of Artisanal Fisher folks in Some Local Government of Rivers State, Nigeria. Journal of Research in Animal Science and Agriculture, 8(2), 32-38.

[17] Ajakaiye, D. O. and Olomola, A. S. (1999). Conceptional and methodological issues in poverty alleviation. Bullion Poverty Alleviation in Nigeria A Publication of the Central Bank of Nigeria, 23(14): 3-5.

[18] Aguero, J. M. (2004). Asymmetric price adjustments and behavior under risk: Evidence from Peruvian agricultural markets. Paper presented at the Selected Paper prepared for presentation at the American Agricultural Economics Association Annual Meeting, Denver, Colorado.

[19] Akinrotimi O.A (2021). Socio Economic Characteristics and Level of Biosecurity Practices among Fish Farmers in Obio-Akpor Local Government of Rivers State. Pp 771-778. In Ogunji, J.O., I.I. Osakwe, R.U. Onyeneke, S.C. Iheanacho \& M.U. Amadi (2021). (eds) Climate Smart Agriculture and Agribusiness Development in Nigeria. Proceedings of the 54th Annual Conference of the Agricultural Society of Nigeria held at Alex Ekwueme Federal University Ndufu Alike, Ebonyi State, Nigeria 31st January - 4 th February, 2021.

[20] George A.D.I and Akinrotimi O.A (2021). Evaluation of Fish Marketing Strategies in Obio Akpor Local Government of Rivers State, Nigeria. Journal of Environmental and Earth Sciences, 7(2), 55-59.

[21] Cliffe, P.T., Akinrotimi, O.A., and Ibemere, I.F. (2011). Promoting women participation in aquaculture as a viable tool for poverty alleviation in the rural areas of Nigeria. Global Approaches to Extension Practice, 7(1): 98-105

[22] Cliffe, P.T., and Akinrotimi, O.A. (2015). Role of Women in Fishery Activities in some Coastal Communities of Rivers State, Nigeria. International Journal of Agricultural Research, 10(1): 24-32.

[23] Amao, J. O., Oluwatayo I. B. and Osuntope F. K. (2006). Economics of Fish Demands in Lagos State, Nigeria. Journal of Human Ecology, 19(1): 25-30.

[24] Ali, E. A., H. I. M. Gaya and T. N. Jampada (2008). Economic analysis of fresh fish marketing in Maiduguri Gamboru Market and KachallariAlau Dam landing site of North-eastern, Nigeria. Journal Of Agriculture And Social Sciences 6(2): 3-5.

[25] Gordon, D., and Hussain, S. (2015). Price determination and demand flexibilities in the ex-vessel market for Tuna in the Republic of Maldives. Journal of Aquaculture Economics and Management, 19(1): 8-28.

[26] Gaya H.I, Mohammed S.T and D.B Bawa (2005).Economic Analysis of Fish Marketing in Yola - North Local Government Area, Adamawa State. University of Maiduguri press, Nigeria,

Citation: Ike-Obasi, J.C." Factors Influencing Market Price of Fish in Obio-Akpor Local Government of Rivers State, Nigeria", International Journal of Innovative Studies in Aquatic Biology and Fisheries (IJISABF), vol. 7, no.1, pp. 26-30, 2021. http://dx.doi.org/10.20431/2454-7670.0701004

Copyright: () 2021 Authors. This is an open-access article distributed under the terms of the Creative Commons Attribution License, which permits unrestricted use, distribution, and reproduction in any medium, provided the original author and source are credited. 